Piotr Roszake and Berenika Seryczyńska

\title{
A Pilgrim Blessing - an Alluring Folklore or Expres- sion of Piety? Theological Insights from the Camino de Santiago
}

\section{Romarski blagoslov - očarljiva folklora ali izraz po- božnosti? Teološki uvidi z Jakobove poti (Camino de Santiago)}

Abstract: This article focuses on various forms of contemporary pilgrims' blessings on the Camino de Santiago, its theological meaning and impact on pilgrims' perception of their way to Compostela, as well as its changes or transformations resulting from interaction of many cultures on the Camino de Santiago. This analysis is based on empirical research among pilgrims realized in 2019 which also includes interpretation of theological sources from medieval up to contemporary literature. Trying to combine theological with sociological aspects of this liturgical rite of pilgrim blessing on the Camino, the spiritual content and cause of its popularity are presented.

Keywords: pilgrimage, Camino de Santiago, ritual, medieval liturgy, shrine

Povそ̨etek: Članek se osredotoča na različne oblike sodobnih romarskih blagoslovov na Jakobovi poti (Camino de Santiago), na njihov teološki pomen in njihov vpliv na okoliščino, kako romarji dojemajo svojo pot do Compostele, prav tako tudi (osebne) spremembe, ki so posledica medsebojnega prepletanja različnih kultur na Jakobovi poti. Analiza temelji na empirični raziskavi romarjev iz leta 2019, ki vključuje tudi interpretacijo teoloških virov od srednjeveške do sodobne literature. V želji, da bi povezali teološke in sociološke vidike liturgičnega obreda romarskega blagoslova na Jakobovi poti, predstavljamo njegovo duhovno vsebino in razloge za njegovo priljubljenost.

Ključne besede: romanje, Jakobova pot (Camino de Santiago), obred, srednjeveška liturgija, svetišče 


\section{Introduction}

One of the characteristic rites in which the pilgrims to Santiago de Compostela take part, regardless of their denominational affiliation, is a blessing imparted in many churches along the Camino. It is sometimes conferred at the beginning of a pilgrimage, during it or at the end of the journey. In many liturgical traditions, special rites of pilgrim blessing associated with the handing of attributes (staff, hat, cloak, etc.) or special formulas of Holy Mass have been preserved. For example, pro iter agentibus in the Gallican and Mozarabic traditions were to stress the new status of the wanderer (Janini 1987). Traditionally, the pilgrim would go from the doorstep of his own house, go to the parish church where he would make his general confession and then, in the presence of the parish community, the priest would bless him and give him the pilgrim's cloak, sack, hat and staff (Mróz 2018, 61). How have these traditions been transformed today? What role do they play in a spiritual journey? Can the blessing of pilgrims be regarded as a folklore phenomenon on the Camino de Santiago? Can it be compared to other rites, such as the Celtic ritual of Queimada? ${ }^{1}$

\section{The origin and types of pilgrim blessing}

The pilgrim blessing makes the people who start the Camino feel like true pilgrims. The practice of setting off on the journey is present in many cultures and religions. They are united by the human intention of seeking truth, by abandoning their habits and opening oneself to new experience, which is an expression of the universal desire to search for the sacred (Skralovnik, 2017, 279; Oviedo 2019).

\subsection{General theological meaning of blessing}

Etymologically, the term blessing derives from the Latin benedicere, which was coined from the combination of two words, bene and dicere denoting, speak well'. It can be understood as saying good words, wishing good things to someone or talking about somebody in a positive way, praising someone and thanking for the received good (Durak 1995, 21-22). The meaning of blessing changes when it is pronounced by God towards humans, in this case, to bless means to create and dispense (dispensation) the good, not only recognize it as when a man is blessing God or someone else. As Gregory the Great observed, the blessing consists in collatio (gathering) of goods and its multiplicatio (multiplication), that is the explication of God's blessing the world after creation according to Genesis 1.

Generally, what fundamentally makes the rite of blessing different from other traditional rituals or rites is the invocation to God, whose power and blessing we want to receive. The contemporary liturgical rite of blessing in Christian tradition usually consists of the following elements, introductory rites, proclamation of God's word, prayer of blessing consisting of praising God's goodness and begging for His help and solemn Trinitarian blessing ending with the sign of the cross. The

Queimada is a ritual to ward off evil spirits. 
minister of the blessing can be a bishop, priest, deacon, acolyte or a lay person by virtue of taking part in the universal priesthood of Christ.

The symbolism of the ritual of blessing is expressed in four dimensions, recalling (the power of the sign, through the power of Christ's salvific work), announcing (action sanctifying the grace of God), committing (to the Christian life) and announcing (the heavenly liturgy) (Sinka 1994, 74). Moreover, the symbolism of the ritual of solemn blessing links the sign of the cross with grace and redemption and eternal life and constitutes a bridge between the sacred and profane spheres (Roszak 2015, 221; Horvat 2017).

\subsection{Biblical meaning of blessing}

In the Old Testament, the blessing (berakhah) was understood as the possibility of praising (Shalom). In the Book of Genesis, God creates man and then blesses him (Gen 1,28) (Globokar 2018, 357). In this sense, the blessing of God essentially leads to the growth of both man and all that belongs to him, his possessions and property (Deut 28,1-13). In the Old Testament, the Patriarchs enjoyed the special blessing of God (Ex 17,7; 26,3). However, since the Jews received from God clearly defined norms of behavior in the form of the Law, they also were given a choice between the obedience related to God's blessing and disobedience which resulted in His curse (Deut 11,26-29). Later, God's blessing was more closely linked to the priest. Aaron's blessing, "The Lord bless you and keep you; the Lord make his face shine on you and be gracious to you; the Lord turn his face toward you and give you peace (Num 6,24-26). Such a formula of blessing which is both praise and thanksgiving to God is present in many psalms. Thus it can be said that in the Old Testament, the concept of blessing has evolved from a simple relationship of mysterious powers which give strength to the development of good to the experience of spiritual closeness of God and man who uses God's blessing in the ordinary activities of his life and as a result his life becomes also his answer through glory and thanksgiving to God (Durak 1995, 24; Platovnjak 2019, 675-276).

Among the sacramentals established by the Church for the sanctification of certain stages and circumstances of Christian life, as well as the use of things indispensable for people, blessings are considered to be the most important. According to the Catechism of the Catholic Church, »every blessing praises God and prays for his gifts. In Christ, Christians are blessed by God the Father »with every spiritual blessing " (Eph 1,3). This is why the Church imparts blessings by invoking the name of Jesus, usually while making the holy sign of the cross of Christ «. The blessing of a Christian is always a participation in the blessing of God Himself, who is the source and beginning of all blessing (Konecki 1997, 16). By their very nature, blessings demand active participation of the faithful.

\subsection{Historical development, medieval marks}

It should be noted that the theme of the blessing of pilgrims has not been comprehensively analyzed, although there are separate studies including pilgrims (Tur- 
ner 1978; Moulin-Stożek 2019). It is worth mentioning two significant authors who focused on this subject.

The first one, Derek A. Rivard, indicates the double aim of blessing, sanctifying the pilgrims and separating them from the rest of society (Rivard 2001, 365-398). In this context, he defines the rite of blessing as the one which formally leads a person from the reality of the profane to the sacred (Roszak 2019). In the Middle Ages, formal crossing of social and religious boundaries was not simple and straightforward, but required an intermediate stage (border state), a rite of passage (Van Gennep 2019), the characteristics of which Derek A. Rivard observed in the blessing of pilgrims (2001, 365-398).

On the other side, Adeline Rucquoi describes the rite of farewell, which in the Middle Ages was linked to the writing of a will by a person deciding to make a pilgrimage to Santiago (Rucquoi 2018, 99). She analyzed the historical and theological meaning of the basic insignia of the pilgrim, a sack (symbol of faith) and a staff which protects against dogs and wolves. Other elements of the outfit such as, a hat (symbol of patience) and a cloak are important but not crucial. Interestingly, although the first formulas of the Holy Mass and the blessings of pilgrims originate from the eighth century, the accompanying ritual of blessing the traveler's outfit appears as late as in the nineteenth century (Rivard 2001). The rite, therefore, evolved from the benedictio peregrinorum to benedictio perarum et baculorum (1252) (Rucquoi 2018, 101). This was probably influenced by the Crusaders' expeditions and by the efforts of the Church to awake the piety of lay people by giving special status to secular activities with certain spiritual functions. In this aspect, the emphasis on the importance of the pilgrim's clothes would correspond to the presentation of the knight's war attributes.

In the first centuries of Christianity the blessings were closely related to the sphere of the sacred, however, in the Middle Ages they also included the sphere of public life. The Rituale Romanum includes the formula of blessing of the king and queen, emperor and empress, the blessing of the knight and the blade of his sword and spear, the blessing of public penitents, pilgrims and crusaders. During the plague and famine, a rite of blessing was performed against rats, mice, locusts and harmful bugs. During the disaster, blessing was imparted to protect people against fire, wind, earthquake and flood.

In the Middle Ages, the pilgrim blessing usually looked as follows, a man in the church received a travel sack and a staff - the main attributes of the pilgrim. At the same time, he received a blessing, which had previously been used in the Roman and Old Spanish rituals for those who set off on the journey, such as travelers and sailors (Ordo ad servicium peregrinorum faciendum in Puszcz 2019, 125). Then he, kneeling in front of the altar, listened to seven penitential psalms, litanies and prayers from Oratio pro iter agentibus. Among the liturgical collections there are rituals which offer a blessing of the clothes, sack and pilgrim's staff. Some of these texts, in addition to enumerating the pilgrims' heavenly guardians, which allows us to specify somewhat the directions of his piety (Our Lady, Rafael - Tobias' guide 
- and Saint Julian, who was previously a custodian) sometimes help to determine which aims, at a given time and place, were considered fundamental (Labande 1958, 159-169).

In confirmation of the above statements in the fourteenth century special ceremony was organized for the inhabitants of Lucca in Italy who wanted to go on a pilgrimage, which allowed the authorities to control those who left the community. The additional customs described by Rucquoi include, for example, the tradition of receiving an onion, , a symbol of poverty and fatigue' by pilgrims in Aurillac, where they were led from the Saint-Géraud monastery church to the parish of Notre-Dame, whereas in Broué, near Dreux, the pilgrims were accompanied by a procession to the ,pilgrims' cross' on the way to Chartres (Rucquoi 2018, 102).

\subsection{Solemn Blessing - a cultural aspect of laying on of hands}

The act of blessing of the faithful liturgically expressed by the gesture of drawing the cross together with the formula uttered »May God bless you, Father, Son and Holy Spirit, go in the peace of Christ « is in accordance with the symbolism of sacred signs, which make human sanctification a reality (Sinka 1994, 73-74). In the context of signs and gestures, the imposition of hands is associated with the posture of an ,orant', which is one of the most common motifs in the early Christian art, in catacomb painting, on sarcophagus reliefs, in monetary art, on tombstones (a standing figure with arms extended upwards and head turned towards the sky). This is a very old prayer posture, linked to the ,accepting' arrangement of hands, the hands with their palms directed upwards are ,receiving', whereas the palms downwards suggest the gesture of ,transmission of power'. This arrangement of hands is described in various contexts, from blessings (manus iniectio - the epicletic gesture of imposing hands) to the gestures described as ,batton' gesture, emphasizing the content of the speech and accompanying, for example, a political speech. The principle which is obeyed is that the palm of the hand upwards ,receives', and downwards - ,transmits or gives', which is associated with the interpretation of the real intentions of the speaker. In various religions there are also numerous examples of such approach to the position of hands (Szybowska 2008, 63).

\section{Pilgrim blessing before, during and after a pilgrimage to Compostela}

\subsection{Pilgrim blessing before setting off on a pilgrimage}

Elements which combine the blessing of pilgrims before, during and after a pilgrimage is a situation in which a person staying in a certain place gives the person who sets off on a journey, continues it or returns from it a good word, accompanied by various gestures (Masłowska 2016, 232). This good word fulfilling the role of a spell, accompanied by gestures, functions in different religious and cultural traditions as a farewell scenario, in which one person transfers to the other the 
energy according to Langacker's concept of energy chain (Langacker 2009, 473). The original scenario of this type of behavior was to say goodbye to someone setting out for a dangerous journey, war or hunting. Saying good-bye to him with a good word, a kiss and a sign of the cross was always aimed at providing the person with a safe passage and return, so that he would get out of the trouble which he may encounter (Długosz-Kurczabowa 2005, 62; Petkovšek 2018).

Often in the blessing prayers there are also symbols based on the Bible. Whereas the most popular medieval formula of pilgrim blessing on the Camino de Santiago used today in Roncesvalles refers to the figure of Abraham and is a direct address to God. This blessing consists of two parts, the first is the invocation of God, and the second is the existential references to the pilgrimage experience (Codd 2008, 20).

Although many of the contemporary popular formulas of blessing refer to God, nevertheless some are addressed directly to the pilgrims, explaining them the significance of their journey. Modern formulas are directed alternately to God, St. James and the pilgrims themselves. It seems to be a reflection of modern humanism demanding a personal and extensive explanation.

\subsection{Pilgrim Blessing during the pilgrimage}

On the Camino, the blessing of the pilgrim is very common. Practically, in every small town where there is a church or chapel and the Holy Mass is celebrated for the pilgrims, usually at the very end of it the priest gives a solemn blessing. Pilgrims, not necessarily practicing Christians, are frequently so impressed with it that they simply say, "Just now I do feel like a real pilgrim«.

Blessing as a liturgical action is not a private act of worship but an event of the ecclesial community. Expressed through signs and visible gestures, it manifests what is happening on the spiritual level, and its aim is to sanctify man and worship God, the giver of all good (Konecki 1997, 13). It is worthy to mention some of these gestures.

Among the gestures associated with the ritual of blessing of pilgrims, observed by the authors of this study as part of their personal experience of walking along the Camino de Santiago, we can distinguish the sprinkling of holy water on the pilgrims standing around the altar who participate in the ritual of blessing given by Fr. Blasa in the church of Santa Maria la Blanca de Fuenterroble de Salvatierra. In the church of Virgen de Santa María del Camino, the pilgrims hold hands during the blessing, then approach the priest and put their hands on each one of them, which was also practised by Fr Tomasz Homa SJ in Villamayor de Monajrdin. In the church in Alto do Cebreiro. Rite of blessing is preceded by the embrace of each participant by the Blessing Fr Fray Paco Castro OFM and in the church of Santiago y San Juan Bautista de Madrid, the pilgrims come to the altar and bow their heads, followed by the rite of blessing. 


\subsection{The Blessing of Pilgrims who visit the Shrine of St. James the Apostle}

Pilgrims coming to Santiago often express their concerns about the imminent return to everyday life. Masses are celebrated in Santiago in the national languages, where pilgrims are invited to participate in additional rituals. An interesting example of the modern blessing of pilgrims is the formula created in 2014 at Monte do Gozo for Polish pilgrims visiting the shrine of St. James the Apostle in Santiago.

The blessing at the end of the way is fundamentally different from that given before and during the pilgrimage. It is directly linked to the achievement of the goal of the pilgrimage, in which the pilgrims who, especially during the Holy Year of James, visit the tomb of St James in the Cathedral of Santiago de Compostela, take part in Mass or celebrate a private prayer, go to the sacrament of Confession (which can take place 15 days before arrival at the Shrine) and receive Holy Communion or receive a plenary indulgence (Mróz 2010, 223). The rite of blessing is therefore directly related to their experience of purifying their souls of sins, their return to their daily duties and the process of implanting the fruits of the pilgrimage when they return to their homes. The blessing at the end of the pilgrimage is a thanksgiving of Divine Providence for all the graces granted during the pilgrimage, for the happy return, as well as for asking for the permanence of the fruits of the pilgrimage (Krzyżak 2014, 96).

\section{Pilgrim Blessing as a form of initiation}

Victor Turner noticed a similarity in the structure of the rites of passage and pilgrimage in the mid-1970s. Unfortunately, he based his work on theoretical sociological studies, not on empirical studies of pilgrims (Bowman 1985, 5). According to Turner, the features of the transitory rites manifested in pilgrimage are, temporary liberation from the mundane, nominally binding structure; freedom from the burden of stress, fear and guilt; movement from the mundane center to the sacred periphery; homogenization of status, simplicity of dress and behavior; reflection on the meaning of basic religious and cultural values; ritual introduction into the fraternal-sister community of pilgrims (Turner and Turner 1978, 3; 34). What Rene Gothóni points out, however, is that the similarities noted by Turner do not automatically make the pilgrimage of the rite of passage a pilgrimage (Gothóni 1993, 103). While the Rite of Passage aims to change a person's social status, the function of the pilgrimage is to facilitate detachment from mundane concerns and unity between the pilgrim and God. The Rite of Passage has the character of an irreversible passage, while the pilgrimage also involves a process of return. Moreover, the pilgrimage is neither inevitable nor obligatory, while the rites of the passage are connected with the natural cycle of life, including the transition from childhood to adulthood.

However, if pilgrimages can be described as a form of ritual, the blessing of pilgrims in this ritual fulfills the role of the rite of passage. The blessing rituals of pil- 
grims differed in various regions with external signs, e.g. in some regions of contemporary Europe pilgrims used to put on a black robe with red crosses and removed shoes (Holub 2016, 99), also for poorer pilgrims parish churches were the place of presenting them with the attributes of a pilgrim, whereas wealthy people received them in private or convent chapels. The ritual of blessing conducted by a priest was celebrated according to the liturgical ceremony of the Catholic Church - »the sign of the cross, profession of faith, reading the Scriptures referring to the pilgrimage, blessing and sprinkling with holy water « (Sinka 1994, 196).

It is interesting that in all forms of rites of passage a characteristic feature is the change (taking away and giving) of a given person. They are frequently used to mark breakthrough periods in human life, related to the transition from one stage of life to another, approaching a certain age or joining a social group. The rituals celebrated on the occasion of physical changes of place, crossing the border, moving, traveling (the sacred journey-pilgrimage, in particular) can also bear some features of rites of passage (Turner 1974, 197)

Referring to the theory of ritual codes, verbal, actional, subjective, personal, temporal, location-related and musical developed by Nikita I. Tolstoy (Tolstoj 1992), the rite of the blessing of pilgrims contains many of these elements which form a coherent image of the rite. American ethnologist Edward Twitchell Hall observes that what really constitutes human identity, no matter where a person was born, is their culture, a comprehensive communication framework, words, actions, poses, gestures, tone and timbre of voice, facial expression, treatment of time and space and material objects, the way a man works, plays, loves, defends himself. All these elements and many others create certain communication systems equipped with meaning understood only by those who know the historical, social and cultural context of behavior (Szybowska 2008, 59).

In the rite of blessing of pilgrims, the pastoral dimension is emphasized because pilgrimages stimulate the faithful to conversion and to deepening of Christian life (Tułodziecki 2018). The rite of blessing strengthens pilgrims in pursuing the pilgrimage (Durak 1995, 28).

\section{What the pilgrims say about the rite of blessing - as shown by interviews}

During the two-month research internship at the Centro Europeo de Peregrinación Juan Pablo II, Monte do Gozo, Santiago de Compostela, Spain (24.07.2019 $-23.09 .2019)$, in-depth interviews $(n=50)$ were conducted with pilgrims according to qualitative research methodology.

The possibility of carrying out interviews at the place where the pilgrims ended their way was an opportunity to get fresh information about their current experience of the pilgrim's blessing in connection with the Camino de Santiago pilgrimage. There were 22 interviews with women and 28 interviews with men. Most of 
them walked Camino for the first time, but some for the second, third or even fourth time. Among the respondents there were representatives of diocesan clergy, consecrated persons, volunteers, high school graduates, students, pensioners, artists, people in other professions and the unemployed. All survey participants gave their consent and the data obtained are in accordance with the ethical standards of the institutional and national research commission and the Helsinki Declaration of 1964 as amended or comparable ethical standards.

Many of the pilgrims surveyed pointed out that thanks to the blessing received, the pilgrim did not feel alone during the journey, that they felt the presence of God, which gave them strength to overcome difficulties and confidence that they could count on God's help. One of the respondents recalls the situation when she got lost during Camino. Then she turned to God: "you gave me a blessing, you sent me here, then help me now «. The blessing also gave the pilgrims joy, sense of happiness and peace of heart. Thanks to the blessing they also felt unity with other pilgrims and with the community of the Church. One of the pilgrims even said that the blessing ,empowered him'. The pilgrims who walked in the company of a priest pointed out that it was important for them both to attend Mass every day and the blessing given by the priest. Among the pilgrims there were also those who, walking in a group of several people along the way, blessed each other and expressed the belief that the road without the blessing would not be the same and would be of lesser value. The woman who walked with her husband also told about the fact that during Camino they blessed each other every morning, they prayed morning prayers and crossed each other's forehead. Among the statements there were also those that when the pilgrims were afraid of something like bed bugs in the place of accommodation, they believed that prayer and blessing could keep them from this danger.

Among the interventions, there was also the focus on the blessing of things along the way, e.g. the poisonous boots or the heavy backpack, which gave respite and comfort. One of the people said that she experienced the blessing of people greeting the pilgrims on the way, which made her feel like she was in first Holy Communion. However, the rituals of the pilgrim's blessing combined with the washing of her legs that she experienced in the Albergue also made her feel more distinctly valuable and proud to be a pilgrim.

One of the people interviewed told about her experience of receiving a blessing before Camino from the prayer community to which she belongs. She was blessed by the priest who looked after the community and then all the members of the community. This blessing was a confirmation for her that the decision to go to Camino was right, that the decision was not influenced by her own whim but by God's inspiration, so she could feel safe and that God would take care of her on the way. The pilgrim's blessing, she experienced along the way gave her a sense of empowerment, and the blessing in Santiago was a confirmation of God's guidance and care. Another 18-year-old pilgrim asked for his mother's blessing before going to Camino from Poland. He recalled with emotion, "We went under the image of Jesus and Our Lady, knelt down and prayed together and Mom bles- 
sed me on the road. It was incredibly important «! The custom of giving a blessing to the road by his parents came from his family home. His parents often made a cross on his forehead with words of blessing in the sense of a good wish for the road. During Camino he discovered the deeper meaning of this custom. He experienced the work of Divine Providence and care and openness to God's presence.

Another person mentioned that before Camino, she went to confession and then also received a blessing on the way,

"Il have to say that the last one now is the fourth Camino /.../ no one has quarrelled on this Camino with anyone, no one has complained, which is also phenomenal - no one has complained once. Although it is not difficult on the route during these hardships. We sang during the tour, we prayed, it was just such joy during the journey. /.../ Maybe it was a blessing that made this Camino so light this year.»

One of the young pilgrims talked about an overnight stay at the Albergue in Guemes, where the experience of common prayer, Holy Mass with pilgrims' blessing, changed his attitude to pilgrimage. During the blessing he felt that the priest blessed him personally. The change concerned the experience of the pilgrimage, not that ॥ have to experience it myself, to enter somewhere, to immerse myself in my thoughts, in prayer ", just to spend this road as it shapes itself and accept what it gives, that if I meet this man here, it is worth spending these moments with him. Here of another, well, it is worth spending those moments with him. And so, it was.

Several pilgrims have described the role of the final blessing in Santiago as giving the opportunity to continue the Camino after returning home and in their daily lives, so that the Camino fruit will remain lasting in their daily lives. One person even said that her Camino is not finished until she receives this final blessing in Santiago, which will be like a seal in the sense, let it happen'.

\section{Conclusion}

The results of the research prove that the rituals of pilgrims' blessing have a deep connection with their experience of the Camino de Santiago wandering. The rite of blessing introduces the pilgrims to the sense of the sacrum experienced during the ordinary activities of the pilgrimage, but understood through the prism of spiritual life, often also referred to by them as the action of God (Platovnjak 2017).

The blessing of objects related to the pilgrimage is also associated with giving them new meanings, usually related to the nature of defending themselves from the hardships and dangers of the way they have undertaken. This experience leads the pilgrims from the economic and technological field to the spiritual experience of reality (Seryczyńska 2019, 179; Delicata 2018).

Rituals of blessing during the Camino are usually connected with the sense of community of pilgrims which expresses the ecclesial nature of the blessing and 
gives strength and protection in the subsequent stages of the journey. The rites of blessing in Santiago, on the other hand, seal the experience of pilgrimage when the goal of the pilgrimage is reached and strengthen the pilgrims during the time of returning to daily life. It is worth emphasizing the link between the final blessing of the pilgrims in Santiago and the theological symbolism of the blessing rituals associated with the experience of redemption and eternal life.

Thus, the liturgical blessing rites still play a significant role in the spiritual and religious experience of the pilgrims going to Compostela. Despite the fact that, according to research, many pilgrims declare their often far from religious motivations for undertaking a pilgrimage (Roszak 2020), nevertheless for many of them this is a link to the former (medieval) community of religious pilgrims and expression of their implicit religiosity.

\section{References}

Bowman, Glenn. 1985. Anthropology of Pilgrimage. In: Makhan Jha, ed. Dimensions of Pilgrimage: An Anthropological Appraisal, 1-9. New Delhi: Inter-India Publications.

Codd, Kevin A. 2008. To the Field of Stars: A Pilgrim's Journey to Santiago De Compostela. Cambridge: William B. Eedrmans.

Delicata, Nadia. 2018. Homo technologicus and the Recovery of a Universal Ethic: Maximus the Confessor and Romano Guardini. Scientia et Fides 6, no. 2:33-53. https://doi.org/10.12775/ SetF.2018.020

Długosz-Kurczabowa, Krystyna. 2005. Słownik etymologiczny języka polskiego. Warszawa: Wydawnictwo Naukowe PWN.

Durak, Adam. 1995. Historyczno-teologiczne aspekty błogosławieństw. Seminare 11:21-36.

Gennep, Arnold van. 2019. The rites of passage. Chicago: The University of Chicago Press.

Globokar, Roman. 2018. Krščanski antropocentrizem in izkoriščevalska drža človeka do naravnega okolja. Bogoslovni vestnik 78, no. 2:349364.

Gothóni, René. 1993. Pilgrimage = Transformation Journey. Scripta Instituti Donneriani Aboensis 15:101-115.

Hołub, Jacek Marian. 2016. Pielgrzymowanie jako rytuał na przykładzie Camino de Santiago wczoraj i dziś. In: Piotr Roszak and Franciszek Mróz, eds. Droga do Composteli: przeszłość $i$ teraźniejszość, 97-108. Cracow: Wydawnictwo Czuwajmy.

Horvat, Saša. 2017. Heideggerov posljednji Bog. Bogoslovska smotra 87, no. 4:745-766.

Janini, José. 1987. Influjos visigóticos en ,Misas de Viajeros' del siglo VIII. Hispana sacra 39:15-24.

Konecki, Krzysztof. 1997. Sprawowanie błogosławieństw wydarzeniem kościelnym. Seminare: Poszukiwania naukowe 13:13-22.

Krzyżak, Lesław. 2014. Pielgrzymki w dokumentach i liturgii Kościoła. Teologia i człowiek 28:117-133. https://org/10.12775/TiCz.2014.061

Labande, Edmond René. 1958. Recherches sur les pèlerins dans l'Europe des Xle et XIle siècles. Cahiers de Civilisation Médiévale 1, no. 2:159-169.

Langacker, Ronald W. 2009. Gramatyka kognitywna. Kraków: Universitas.

Masłowska, Ewa. 2016. Dobre słowo jako tekst magiczny: Życzenie - pozdrowienie - błogosławieństwo. Język a Kultura 26:231-243. https:// doi.org/10.19195/1232-9657.26.19

Moulin-Stożek, Daniel. 2019. Pilgrims' play on the Santiago Way. International Journal of Religious Tourism and Pilgrimage 7, no. 5:24-32. https://doi.org/10.21427/ZFQ1-XQ84

Mróz, Franciszek. 2010. Wizyta Metropolity Santiago de Compostela, arcybiskupa Juliana Bario Bario w Polsce. In: Antoni Jackowski, Franciszek Mróz and Iwona Hodorowicz, eds. Kult św. Jakuba Apostoła na szlakach pielgrzymkowych do Santiago de Compostela, 223-229. Kraków: Wydawnictwo Czuwajmy.

- - - 2018. Polscy rycerze i pielgrzymi w drodze do Composteli - przestrzeń, sacrum, czas. In: Łukasz Stefaniak, ed. Rycerze i pielgrzymi, 55-78. Warszawa: Konfraternia Świętego Apostoła Jakuba Starszego.

Oviedo, Lluis. 2019. Meaning and Religion: Exploring Mutual Implications. Scientia et Fides 1:2546. https://doi.org/10.12775/SetF.2019.002

Petkovšek, Robert. 2018. Svoboda med žrtvovanjem in darovanjem. Bogoslovni vestnik 78 , no. 1:33-51. 
Platovnjak, Ivan. 2017. Vpliv religije in kulture na duhovnost in obratno. Bogoslovni vestnik 77, no. 2:337-344.

- - - 2019. To Live a Life in Christ's Way: the Answer to a Truncated View of Transhumanism on Human Life. Bogoslovni vestnik 79, no. 3:669-682.

Puszcz, Teodor. 2019. Liturgische Texte zu Ehren der Heiligen drei Könige. Roczniki Teologiczne 66, no. 8:125-138. https://doi.org/10.18290/ rt.2019.66.8-9

Rivard, Derek A. 2001. "Pro Iter Agengibus«: the ritual blessing of pilgrims and their insignia in a pontifical of southern Italy. Journal of Medieval History 27:365-398. https://doi.org/10.1016/ S0304-4181(01)00016-1

Roszak, Piotr. 2015. Camino de Santiago i devotio post-moderna: W poszukiwaniu tożsamości pielgrzyma w dobie ponowoczesnej bezdomności. In: Piotr Roszak and Waldemar Rozynkowski, eds. Camino Polaco: Teologia-sztuka-historia-teraźniejszość. Vol. 2, 219-238. Toruń: Wydawnictwo Naukowe UMK.

- - - 2019. Sacred and Space in Post-Secular Pilgrimage: The Camino de Santiago and Relational Model of the Sacred. International Journal of Religious Tourism and Pilgrimage 7, no. 5:33-40. https://doi.org/10.21427/v5r3-j416

- - - 2020. Mute Sacrum: Faith and Its Relation to Heritage on Camino de Santiago. Religions 11, no. 2:87-100. https://doi.org/10.3390/ rel11020070

Rucquoi, Adeline. 2018. Mille fois à Compostelle: pèlerins du moyen âge. Paris: Les Belles Lettres.
Seryczyńska, Berenika. 2019. Dialog międzykulturowy w kontekście Camino de Santiago. In: Piotr Roszak and Waldemar Rozynkowski, eds. Camino Polaco: Teologia-Sztuka-Historia-Teraźniejszość. Vol. 4, 167-180. Toruń: Wydawnictwo Naukowe UMK.

Sinka, Tarsycjusz. 1994. Zarys liturgii. Kraków: Instytut Teologiczny Księży Misjonarzy.

Skralovnik, Samo. 2017. The dynamism of desire: the root hmd in relation to the root 'wh. Vetus Testamentum 67, no. 2:273-284.

Szybowska, Antonina. 2008. Ewolucja gestów: O sposobach badania ,kinetyki człowieka' - propozycja metodologiczna. Teksty z Ulicy Zeszyt memetyczny 12:55-65.

Tolstoj, Nikita. 1992. Język a kultura: niektóre zagadnienia słowiańskiej etnolingwistyki. Etnolingwistyka 5:15-25.

Tułodziecki, Tomasz. 2018. „Nasza ojczyzna jest w niebie«: Wykład św. Pawła na temat rzeczy ostatecznych w Liście do Filipian (Flp 3,1-4,1). Biblica et Patristica Thoruniensia 11, no. 1:101127. https://doi.org/10.12775/BPTh.2018.005

Turner, Victor. 1974. Dramas, Fields, and Metaphors: Symbolic Action in Human Society. New York: Cornell University Press.

Turner, Victor, and Edith Turner. 1978. Image and Pilgrimage in Christian Culture: Anthropological Perspectives. New York: Columbia University Press. 